Kayahan Cokuk ${ }^{\mathrm{a}}$

Van Yuzuncu Yıl University

Van, Turkey

Assoc. Prof. Dr. Ishak Kozikoglu ${ }^{b}$

Van Yuzuncu Yıl University

Van, Turkey
Original scientific paper

UDC: $37.064 \cdot 3$

DOI: $10.5937 /$ istrped2001013C

\title{
SCHOOL ADAPTATION PROBLEMS OF PRIMARY SCHOOL STUDENTS IN MIXED-AGE CLASSROOMS ${ }^{1}$
}

\begin{abstract}
The aim of this study is to determine school adaptation problems of primary school students according to teachers' opinions. In this study, embedded mixed method design was used. The sample of this study consists of 909 first grade primary school students and 30 classroom teachers determined by stratified purposeful sampling method. "Adaptation to School Scale" and "semi-structured interview form" were used for data collection. In this study, descriptive statistics and differential analysis were used for quantitative data and descriptive analysis technique was used for qualitative data. As a result of the study, it was determined that 60-65 months old students sometimes experienced adaptation problems, while the students of 66-71 and 72-84 months old almost never experienced adaptation problems. In interviews, teachers stated that as their students' ages decreased, their school adaptation problems increased. Furthermore, school adaptation problems were found to be higher in students who study in Van province and did not receive preschool education. Accordingly, it can be suggested to prepare effective school adaptation curricula for primary school students.
\end{abstract}

Keywords: Mixed-age classrooms, primary school students, school adaptation problems.

\section{Introduction}

People may experience adaptation problems in situations that they face for the first time. Primary school, which is a new environment for children separating from their families in early childhood, entails many new situations for the child. In this respect, it is quite likely for children to experience school adaptation problems.

Yavuzer (2014) defined adaptation problems as emotional disorders that occur when negative effects of the environment are combined with the difficulties caused by individual developmental stages. Adaptation problems arise due to various reasons, reflecting internal conflicts of children to some extent (Yorukoglu, 2006). Adaptation problems can be

\footnotetext{
a K1y1h1n@hotmail.com

bishakkozikoglu@yyu.edu.tr

${ }^{1}$ This study was obtained from first author's master thesis titled as "School Readiness and Adaptation Problems of Students Who Begin Primary School at Different Age Groups" and funded by Scientific Research Projects Coordination Unit of Van Yuzuncu Yıl University as a project numbered SYL-2018-7251.
} 
expressed as the state of depression that occurs when the environmental effects are combined with the child's internal problems. It can be said that the children facing adaptation problems are likely to experience self-confidence problems and feel inadequate in overcoming these problems. In this process, children's relations with their environment may be tense and problematic because they may exhibit behaviors such as aggression, irritability, incompatibility, quarreling, escaping from school, revolting and breaking the rules (Yorukoglu, 2003).

The school adaptation, identified by Onder and Gulay (2010) as being sufficient for learning to fulfill the duties and responsibilities required by the school and classroom, can be defined as student's ability to fulfill the requirements of the school environment and establish positive social relations. Ladd, Birch, and Buhs (1999) describe school adaptation as a concept that involves positive interactions between students, their classmates and teachers in classroom and out-of-class activities. On the other hand, Birch and Ladd (1997) correlated school adaptation with school success, social interaction, interest and comfort. Children, who have not separated from their families before, are likely to be excited, afraid, and cry in a classroom environment filled with people that they do not know (Durak, 2011). Students experience more problems with school adaptation, especially in the first weeks of the school. It may take some time for students to get used to this new situation. However, there may be students who experience these problems less than their peers (Ozgenel, 1992).

Adaptation, defined as the ability of individuals to establish regular and effective relationships with their environment (Dogan, Kelleci, Sabanciogullari \& Aydin, 2008), is one of the most serious phenomena encountered especially in the first weeks of the school. Students face with many new situations when they start to school. The child's teacher and parents expect him/her to keep up with the new situation. However, the children may experience adaptation problems in this process such as rejection of the school, crying in the lesson, asking family members, fatigue, waiting for constant help from the teacher, being uninterested to school and lessons, lack of school perception, desire to play continuously, etc (Ozarslan, 2014).

School adaptation has many effects on the child and affects school success, attitudes and behaviors of children (Birch and Ladd, 1997; Ladd 2003; Ladd and Burgess, 2001). Many variables such as teacher-student and peer relationships, readiness for school, parental attitudes affect students' school adaptation (Akis, 2018; Basaran, Gokmen \& Akdag, 2014). Factors such as physical structure of the school and environmental conditions also affect school adaptation process (Ensar \& Keskin, 2014; Memisoglu \& Ismetoglu, 2013). In addition, there are individual factors that affect the child's school adaptation such as cognitive, physical and affective developmental characteristics.

One of the factors affecting the child's school adaptation is parent-child relationship. Ustabas (2017) stated that children who grew up with good family relations are more adaptable. Another variable affecting school adaptation is peer relationships. Demirtas (2016) stated that school adaptation of children was positively affected by their positive relationships with their peers. It can be said that one of the most important variable affecting school adaptation is the characteristics of the child. Children who are more dependent on parents, lack of self-esteem, cannot make friendships, have poor social relations, lack of school perception and have poor self-efficacy are more likely to experience longer and more problematic adaptation to school. Another variable that affects school adaptation is the teacher. According to Goldberg (2006), one of the most important factors determining the child's adaptation to school is the teacher- 
student relationship. In this case, it can be said that school adaptation is not only a situation that the child has to solve alone, but the child is adapting to the school with the support of all people around him/her (Fabian, 2000). It can be said that children starting school go into searching of identity (Gill et al., 2006) and experience a new adaptation process. The child has to adapt to the rules, duties and responsibilities of his/her new environment, friends, teachers and new status (Fabian, 2000). Students' adaptation to this new situation is highly effective on school achievement (Gill et al., 2006). Pianta and Kraft-Sayre (1999) state that adaptation to school has significant impacts on child's school career. Students will be more successful in the school environment in which they feel well. Students who have acquired the skills required for primary school will have a positive attitude towards the school. According to Entwisle and Alexander (1998), effective adaptation to school will help them develop positive feelings about their own competencies.

Ensuring the attendance of primary school students, their positive attitude towards the school will facilitate their social adaptation in school (Aypay, Aypay \& Demirhan, 2009). The psychological adaptation of the student to school is possible with overcoming the challenges and self-acceptance (Basaran, 1994). Accordingly, both the personal characteristics of the student and environmental factors affect the child's school adaptation.

\subsection{Aim and Importance of the Study}

The aim of this study is to determine school adaptation problems of primary school students in mixed-age classrooms according to teachers' opinions. For this purpose, the following questions are addressed.

1. How often do the students experience school adaptation problems?

2. Do the school adaptation problems of the students show significant difference according to;
a) Age group
b) Gender
c) Province
d) Receiving preschool education or not?
3. What are teachers 'opinions concerning students' school adaptation in mixed-age classrooms?

Adaptation of children to the school especially in the beginning of primary school is crucial for their academic achievement, social and emotional behaviors. It also affects the future learning and life processes of the students. In addition to social and environmental factors, individual factors such as cognitive, affective and psychomotor developmental characteristics of children are also effective on school adaptation process which is of such importance in children's life. Therefore, it can be said that there is a need for studies to determine school adaptation problems of first grade students in mixed-age classrooms. Therefore, this study is considered to be important in terms of comparative analysis of primary school students' school adaptation at different age groups. Also, it is believed that this study will contribute to the target literature in terms of providing more comprehensive and generalizable data by using mixed method and gathering data from different provinces across Turkey. 


\subsection{Research Model}

2. Method

In this study, mixed research method was used. Mixed research method, in which at least one quantitative and one qualitative research method is used together (Johnson \& Christensen, 2008), offers researchers the opportunity to minimize the drawbacks arising from the natural limitations of qualitative and quantitative data and exploit the superior aspects of these methods (Johnson \& Onwuegbuzie, 2004). By combining both quantitative and qualitative data, it provides a wide range of opportunities for understanding research problems. In other words, it is aimed to better understand research problems by supporting the weakness of one research method with the strengths of the other research method (Creswell, 2005; Creswell, 2014). In this study, data triangulation was ensured by using scale and interview form because of the fact that the scale provides the opportunity to work on large samples and the interview form provides more comprehensive data concerning research problems.

In this study, embedded mixed pattern was used. In embedded mixed pattern, quantitative and qualitative data are collected simultaneously. One of the data plays a supporting, explanatory and expanding role in the other data (Firat, Kabakci Yurdakul \& Ersoy, 2014). In this study, it is considered that embedded mixed pattern is suitable for the purpose of this study since quantitative and qualitative data were collected simultaneously and qualitative data was used to support, explain and expand the quantitative data.

\subsection{Population and Sample}

The study population of this study consists of first grade students at different age groups (6065 months, 66-71 months and 72-84 months) starting primary education in public schools of Istanbul, Kayseri, Gaziantep and Van provinces within 2017-2018 academic year. According to the data obtained from the Ministry of National Education Strategy Development Presidency (2018), 313.433 first grade primary school students are enrolled in public schools affiliated to the Ministry of National Education; 214.834 in Istanbul, 22.328 in Kayseri, 51.696 in Gaziantep and 24.575 in Van.

In this study, purposeful sampling method was used. Purposeful sampling allows comprehensive analysis of situations that can best represent the population and offer rich data (Buyukozturk, Cakmak, Akgun, Karadeniz \& Demirel, 2016). In this study, stratified purposeful sampling method was used in which the study population is separated into strata, the sample is selected from the strata to reflect the characteristics of the population and make comparisons. The main element that distinguishes this method from random stratified sampling is that the selection of units for sampling is not random (Buyukozturk et al., 2016; Patton, 2002).

In this study, when strata were formed, samples were taken from different socio-economic development levels on the grounds that the socio-economic development level of the provinces could affect the school adaptation of the students. Accordingly, the results of "Socio-Economic Development Ranking Survey of Provinces and Regions 2013" report published by the Ministry of Development were taken as basis. According to this report; 81 provinces were classified into four levels as high, medium-high, medium-low and low socioeconomic development level (Ministry of Development, 2013). Therefore, four provinces representing each stratum were determined: Istanbul at high socio-economic development 
level, Kayseri at medium-high socio-economic development level, Gaziantep at medium-low socio-economic development level, Van at low-socio-economic development level. 909 students were included in the sample. The personal characteristics of the students in the sample are presented in Table 1.

Table 1. Personal Characteristics of the Students in the Sample

\begin{tabular}{lll}
\hline Characteristics & Category & Number \\
\hline Gender & Female & 474 \\
& Male & 435 \\
\hline Province & Istanbul & 216 \\
& Kayseri & 206 \\
& Gaziantep & 235 \\
\hline Age Group & Van & 252 \\
& $60-65$ months & 248 \\
& $66-71$ months & 364 \\
\hline Total & $72-84$ months & 297 \\
\hline
\end{tabular}

In Table 1, it is seen that 474 of the students are female and 435 are male. 216 of the students are studying in Istanbul, 206 in Kayseri, 235 in Gaziantep and 252 in Van. 248 of the students are between 60-65 months, 364 of them are between 66-71 months and 297 of them are between 72-84 months. According to Cingi (1994), if the number of population is 500.000, 665 individuals in the sample are considered sufficient to represent the population at .01 significance level (Cited in Buyukozturk et al., 2016). In this case, it can be said that the sample of this study is large enough to represent the population.

In addition, 30 teachers determined by maximum variation sampling method were interviewed in order to gather more comprehensive data about the research problems. In maximum variation sampling method, different homogeneous situations are selected from the population that are suitable for the purpose of the study (Buyukozturk et al., 2016). In the selection of teachers, diversity has been provided by taking their gender, province and professional experience into account. 13 of the teachers are female and 17 are male. Seven of the teachers are working in Istanbul, eight in Kayseri, seven in Gaziantep and eight in Van. 11 of the teachers work in the city center, nine in the district center and 10 in the village schools. Nine of the teachers have 1-4 years of professional experience, eight of them have 5-10 years of professional experience and 13 of them have professional experience of 11 years and over.

\subsection{Data Collection Tools}

2.3.1. School Adaptation Scale: The scale, developed by Ozarslan (2014) and scored by classroom teacher, is a five-point Likert type and consists of 15 items. The Cronbach Alpha internal consistency coefficients of the scale were found to be "0.92" and "0.90" for 60-71 months and 72-84 months old children (Ozarslan, 2014). In this study, Cronbach Alpha internal consistency coefficient of the scale was found to be 0.95 . Accordingly, the data obtained from the scale can be said to be reliable (Buyukozturk et al., 2016).

2.3.2. Semi-structured Interview Form: In this study, a semi-structured interview form was developed by the researchers. In the process of developing the interview form; The draft interview form prepared was sent to three experts from the Department of Educational Sciences and Turkish Education in order to get expert opinion, and in accordance with the 
opinions and suggestions of the experts, necessary revisions were made in terms of language and content. In the draft interview form; the questions, which were largely consensus among the experts, were taken exactly and the questions that needed to be revised were made more understandable in line with the feedback and suggestions of the experts. As a preliminary application of the interview form, three classroom teachers were interviewed and it was checked whether the questions in the interview form were correctly understood by the teachers and the form was suitable for the purpose of the study. Accordingly, it was found out that the questions in the interview form were clearly understood by the teachers and served the purpose of the study.

The following steps were taken in data collection process:

1. In the selected provinces, the schools were divided into three strata as low, middle and high socio-economic development level by taking expert opinion. A total of 48 primary schools were identified, 12 from Istanbul, 14 from Kayseri, 10 from Gaziantep and 12 from Van.

2. Each teacher in determined schools was asked to randomly select three to six students from different age groups (60-65 months, 66-71 months and 72-84 months). Classroom teachers were asked to fill the scales about randomly selected students.

3. A total of 290 teachers were contacted and feedback was received from 238 teachers. In this case, approximately three to five students were selected by each teacher.

4. The data collection process took approximately 8 weeks.

The main application of the semi-structured interview form was conducted with a total of 30 teachers working in the provinces of Istanbul, Kayseri, Gaziantep and Van. The interviews were conducted face-to-face with the teachers working in Van in a suitable environment, but the interviews were conducted using the "Skype" program with the teachers working in Istanbul, Kayseri and Gaziantep. Interviews with each teacher lasted approximately 30-35 minutes.

\subsection{Data Analysis}

In this study, the arithmetic mean and standard deviation values of the scale scores were examined to determine the school adaptation problems of the students. These values were interpreted as very low between "1-1.79", low between "1.80-2.59", medium between "2.603.39", high between "3.40-4.19" and very high level between "4.20-5.00" (Buyukozturk et al., 2016). The t-test for independent samples was used to determine whether students' school adaptation problems differ significantly according to gender and receiving preschool education; one-way ANOVA test was used to determine whether students' school adaptation problems differ significantly according to age group and province. In addition, in t case of a significant difference in ANOVA test, Scheffe test was used to determine which groups caused the difference.

In this study, descriptive analysis technique was used to analyze the data obtained from the interviews. The data obtained through qualitative data collection techniques are analyzed and interpreted through descriptive analysis (Karatas 2015; Punch, 2014). Descriptive analysis consists of four steps. These steps are creating a thematic framework for descriptive analysis, processing data according to themes, defining and interpreting the findings (Yidirim \& Simsek, 2011). In this study, by following these steps, themes were created during data analysis process, data were classified, described and interpreted by coding. The data were supported 
with direct quotations in order to support the findings and to reflect the opinions of the teachers clearly. Teachers were given a code number $\left(\mathrm{T}_{1}, \mathrm{~T}_{2}, \mathrm{~T}_{3}\right)$ in direct quotations.

In this study, detailed information was given about the role of the researchers and the participants in order to ensure external reliability. In order to increase internal reliability, some of the data were coded separately by two different coders. The percentages of the intercoders agreement was found to be $91 \%$ by using the formula suggested by Miles and Huberman (1994) (Reliability = consensus / consensus + disagreement). Accordingly, the coding can be said to be sufficiently reliable (Miles \& Huberman, 1994). In order to increase internal validity, the integrity and consistency of the data were continuously checked, and processes such as preparation of interview form, data collection and analysis were explained in detail to increase external validity.

\section{Results}

\subsection{Quantitative Results}

In this study, arithmetic mean and standard deviation values calculated by the teachers' responses to the scale items are presented in Table 2.

Table 2. Arithmetic Mean and Standard Deviation Values Concerning Primary School Students' School Adaptation Problems

\begin{tabular}{|c|c|c|c|c|c|c|c|c|c|}
\hline \multirow{2}{*}{$\begin{array}{l}\text { School Adaptation Problems } \\
\text { Items }\end{array}$} & \multicolumn{3}{|c|}{$60-65$ months } & \multicolumn{3}{|c|}{ 66-71 months } & \multicolumn{3}{|c|}{ 72-84 months } \\
\hline & $N$ & $\overline{\mathbf{X}}$ & SS & $N$ & $\overline{\mathbf{x}}$ & SS & $N$ & $\overline{\mathbf{x}}$ & SS \\
\hline 1. School rejection & 248 & 2.18 & 1.17 & 364 & 1.58 & 0.91 & 297 & 1.55 & 0.97 \\
\hline 2. Crying in class & 248 & 2.22 & 1.22 & 364 & 1.60 & 0.92 & 297 & 1.60 & 0.94 \\
\hline $\begin{array}{l}\text { 3. Willingness to be with family } \\
\text { members }\end{array}$ & 248 & 2.31 & 1.29 & 364 & 1.78 & 1.08 & 297 & 1.71 & 1.07 \\
\hline 4. Failing to wake up in the morning & 248 & 2.23 & 1.17 & 364 & 1.63 & 0.90 & 297 & 1.51 & 0.78 \\
\hline $\begin{array}{l}\text { 5. Arriving late for class (no } \\
\text { perception of time) }\end{array}$ & 248 & 2.32 & 1.21 & 364 & 1.64 & 0.87 & 297 & 1.55 & 0.90 \\
\hline 6. Getting tired early & 248 & 3.09 & 1.24 & 364 & 1.98 & 1.00 & 297 & 1.84 & 1.01 \\
\hline $\begin{array}{l}\text { 7. Continuously waiting for help from } \\
\text { the teacher }\end{array}$ & 248 & 3.14 & 1.24 & 364 & 2.01 & 1.07 & 297 & 1.87 & 1.11 \\
\hline $\begin{array}{l}\text { 8. Lack of interest in school and } \\
\text { courses }\end{array}$ & 248 & 3.00 & 1.29 & 364 & 1.93 & 1.10 & 297 & 1.88 & 1.11 \\
\hline $\begin{array}{l}\text { 9. Refusing to participate in class } \\
\text { activities }\end{array}$ & 248 & 2.65 & 1.27 & 364 & 1.71 & 0.98 & 297 & 1.68 & 0.95 \\
\hline $\begin{array}{l}\text { 10. Showing infantile behaviors that } \\
\text { are not suitable for his/her age }\end{array}$ & 248 & 2.63 & 1.33 & 364 & 1.75 & 0.98 & 297 & 1.62 & 0.96 \\
\hline $\begin{array}{l}\text { 11. Lack of school and course } \\
\text { perception }\end{array}$ & 248 & 2.81 & 1.36 & 364 & 1.82 & 1.03 & 297 & 1.71 & 1.04 \\
\hline $\begin{array}{l}\text { 12. Underdevelopment of small } \\
\text { muscle skills }\end{array}$ & 248 & 2.96 & 1.27 & 364 & 1.86 & 1.00 & 297 & 1.66 & .092 \\
\hline 13. Willing to play constantly & 248 & 3.17 & 1.27 & 364 & 2.21 & 1.19 & 297 & 1.96 & 1.12 \\
\hline $\begin{array}{l}\text { 14. Frequent complaining of } \\
\text { abdominal pain }\end{array}$ & 248 & 2.45 & 1.31 & 364 & 1.72 & 0.92 & 297 & 1.63 & 0.97 \\
\hline 15. Lying for not go to school & 248 & 2.04 & 1.21 & 364 & 1.47 & 0.84 & 297 & 1.42 & 0.83 \\
\hline TOTAL & 248 & 2.61 & 0.94 & 364 & 1.78 & 0.75 & 297 & 1.68 & 0.72 \\
\hline
\end{tabular}


When Table 2 is examined, it is seen that $60-65$ months old students sometimes experience school adaptation problems $(\bar{X}=2.61)$. They experience school adaptation problems more such as willing to play continuously $(\bar{X}=3.17)$, continuously waiting for help from the teacher ( $\bar{X}=3.14)$, getting tired early $(\bar{X}=3.09)$, lack of interest in school and courses $(\bar{X}=3.00)$, underdevelopment of small muscle skills $(\bar{X}=2.96)$. It is seen that $66-71$ months old students almost never experience school adaptation problems $(\bar{X}=1.78)$, and they experience school adaptation problems more such as willing to play continuously $(\bar{X}=2.21)$ and continuously waiting for help from the teacher $(\bar{X}=2.01)$. Similarly, it is seen that $72-84$ months old students almost never experience school adaptation problems $(\bar{X}=1.68)$. The most striking school adaptation problems of 72-84 months old students are willing to play continuously $(\bar{X}=1.96)$, lack of interest in school and courses $(\bar{X}=1.88)$, and continuously waiting for help from the teacher $(\bar{X}=1.87)$.

Table 3 shows ANOVA test results to determine whether school adaptation problems of primary school students differ significantly according to age groups.

Table 3. ANOVA Results Concerning Primary School Students' School Adaptation Problems According to Age Groups

\begin{tabular}{llllllll}
\hline Scale & $\begin{array}{c}\text { Source of } \\
\text { Variance }\end{array}$ & $\begin{array}{l}\text { Sum of } \\
\text { Squares }\end{array}$ & df & $\begin{array}{c}\text { Mean of } \\
\text { Squares }\end{array}$ & F & p & Significance \\
\hline School & Between & 141.032 & 2 & 70.516 & 110.388 & .000 & $1>2$ \\
Adaptation & groups & 578.754 & 906 & 0.639 & & & $1>3$ \\
Problems & Within groups & 719.786 & 908 & & & & \\
& Total & & & & & & \\
& & & & & &
\end{tabular}

1- "60-65 months", 2- "66-71 months ", 3- "72-84 months"

According to Table 3, it is seen that students' school adaptation problems differ significantly according to age groups $(F(2,906)=110.388, p<.05)$. As a result of the Scheffe test, there is a significant difference between 60-65 months old students and 66-71, 72-84 months old students in favor of 60-65 months. In other words, 60-65 months old students experience school adaptation problems more than other age groups.

Table 4 shows $t$ test results to determine on whether school adaptation problems of primary school students differ significantly according to gender.

Table 4. T Test Results Concerning Primary School Students' School Adaptation Problems According to Gender

\begin{tabular}{llllllll}
\hline Scale & Gender & $\mathbf{N}$ & $\bar{X}$ & ss & sd & t & p \\
\hline \multirow{2}{*}{ School Adaptation Problems } & Female & 474 & 1.97 & 0.89 & & & \\
& Male & 435 & 1.98 & 0.89 & 907 & -.288 & .774 \\
\hline
\end{tabular}


According to Table 4, students' school adaptation problems do not show significant difference according to gender $\left.\left(t{ }_{907}\right)=-.288, p>.05\right)$. In other words, there is no significant difference between school adaptation problems of female and male students.

Table 5 shows ANOVA test results on whether school adaptation problems of primary school students differ significantly according to the province in which they study.

Table 5. ANOVA Results Concerning Primary School Students' School Adaptation Problems According to the Province

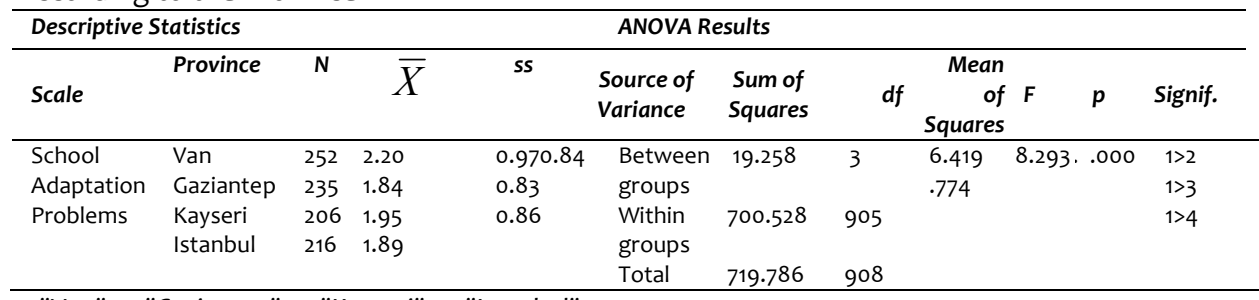

1-"Van", 2-"Gaziantep", 3-"Kayseri", 4- "Istanbul"

When Table 5 is examined, it is seen that the students studying in Van province have the highest mean values $(\bar{X}=2.20)$ compared to the students studying in other provinces according to the scores obtained from the school adaptation problems scale. Although the mean values of the students in Gaziantep, Kayseri and Istanbul in terms of school adaptation problems are close to each other, it is seen that the students in Gaziantep have the lowest mean values concerning school adaptation problems $(\bar{X}=1.84)$. In addition, it is seen that students' school adaptation problems differ significantly according to the province $\left(\mathrm{F}\left({ }_{3,905}\right)=\right.$ 8.293, $p<.05$ ). As a result of the Scheffe test, it is seen that there is a significant difference between the students studying in Van and the students studying in other provinces in terms of school adaptation problems in favor of the students studying in Van. In other words, students studying in Van experience more school adaptation problems than students in other provinces.

Table 6 shows t-test results on whether school adaptation problems of primary school students show significant difference according to receiving preschool education or not.

Table 6. T Test Results Concerning Primary School Students' School Adaptation Problems According to Receiving Preschool Education

\begin{tabular}{llllllll}
\hline Scale & $\begin{array}{l}\text { Receiving Preschool } \\
\text { Education }\end{array}$ & $\mathbf{N}$ & $\bar{X}$ & ss & sd & t & p \\
\hline School Adaptation & Yes & 657 & 1.85 & 0.83 & & & \\
$\begin{array}{l}\text { Problems } \\
\text { No }\end{array}$ & 252 & 2.30 & 0.97 & 907 & -7.068 & .000
\end{tabular}

As it is seen in Table 6, students' school adaptation problems show a significant difference in favor of the students who did not receive preschool education $\left.\left(t{ }_{907}\right)=-7.068, p<.05\right)$. In other words, students who did not receive preschool education experience school adaptation problems more. 


\subsection{Qualitative Results}

In the interviews with the teachers, the majority of the teachers stated that as students' age decreases, they see the school as a playground and they act with the desire to play continuously. Therefore, they pointed out that school perception has not developed in students. Some of teachers' opinions are as follows:

"The school perception was not developed in young children, because they are in playing period. But older students have the awareness that they should learn to read and write as they are ready for the school." (T3)

"The children are in playing period at that time. I'm talking about the little ones, 60-65 months old. They have a good time with their friends during the play activities. But when we goto class, they want to get away. School perception did not develop; they think why I am here." (T4)

"60-65 months old children do not care about the courses. They don't take school seriously. They are always willing to play, especially small children." (T5)

As stated above, it is seen that as students' age decreases, their desire to play games increase. It is seen that teachers have difficulty in attracting students' attention. Teachers stated that especially 60-65 months old students' school perception has not developed, they are not aware of why they have came to school, and they think school as a playground. Furthermore, teachers pointed out that 60-65 months old students get tired early. Some of teachers' opinions are as follows:

"Especially 60-65 months children's small muscle skills have not developed. I have never had an adaptation problem with children of normal school age. Young children are amazing especially in line work. They get tired early and don't want to do it." (T7)

"Young children's small muscle skills have not improved. They're having trouble keeping a pen. They can't take responsibility in class. They get bored quickly because they get tired. Therefore, you cannot teach for a long time." (T12)

"We observe fatigue in these children very quickly, since the small muscle skills of young children have not developed. We observe them behaviors such as not wanting to do it, not taking responsibility, etc."(T15)

As stated above, as students' age decreases, small muscle development decreases and consequently early fatigue and boredom occur in children. In addition, teachers stated that they observed school adaptation problems such as crying, escaping from school in small children. Some of teachers' opinions are as follows:

"We couldn't get a 60-65 month old child into the classroom. One of them was crying. At the end of two days, his father said what we will do. I said you're going to take him next year. He's underage anyway, so he doesn't want to come to school." (T21)

"Especially in the first weeks of school, the younger age group cried and escaped from the classroom many times. But we didn't have any problems in older age groups." (T29)

As mentioned above, especially 60-65 months old students were not very willing to come to school, they exhibited crying behaviors and escaping from school when they came to school. As it is understood from teachers' opinions, especially 60-65 months old students have problems such as getting tired early, underdevelopment of small muscle skills, not to 
participate in courses, lack of motivation and school perception, desire to play continuously.

\section{Discussion, Conclusion and Suggestions}

In this study, it was concluded that $60-65$ months old students experience school adaptation problems at medium level, while 66-71 months old students experience at low level and 72-84 months old students experience at very low level. In addition, it was determined that $60-65$ months old students had more adaptation problems compared to other age groups. The school adaptation problems most frequently experienced by $60-65$ months old students were determined as willing to play continuously, waiting for help from the teacher continuously, getting tired early, lack of interest in school and courses, underdevelopment of small muscle skills. In the interviews conducted with the teachers, conclusions supporting the quantitative results were reached. Accordingly, teachers stated that 60-65 months old students had more adaptation problems than other students. Teachers stated that 60-65 months old children had school adaptation problems such as getting tired early, underdevelopment of small muscle skills, being reluctant to participate in courses, lack of motivation and school perception and willing to play continuously. These results coincide with the results of similar studies in the literature. Similarly, Fidan, Tasci and Yilmaz (2013) found that 60-66 months old students were bored quickly, had difficulty in complying with the classroom rules, lacked of school perception and motivation. Gunduz and Caliskan (2013) revealed that 60-66 months old students had school adaptation problems such as underdevelopment of small muscle skills, slow learning and fatigue. Basar (2013) concluded that 60-66 months old children had difficulty in performing activities such as holding pencil, coloring, and line work that required the use of fine muscle skills in the first weeks of school. Sirem (2014) determined that 60-66 months old students had problems with school adaptation. In the study conducted by Uzun and Alat (2014), teachers stated that students who started school at an early age had problems such as not being able to separate from family and come to school, not to be able to fulfill their responsibilities and communicate. Similarly, in the study conducted by Kahramanoglu, Tiryaki and Canpolat (2014), teachers stated that 60-66 months old children were shy, so they had communication problems such as expressing themselves, socializing and communicating with others, as well as not wanting to separate from the family. Therefore, it was determined that teachers could not adapt these children to the school (Aslan, 2014; Cerit, Akgun, Yildiz \& Sosyal, 2014; Gunduz \& Ozarslan, 2017; Topdemir, 2014). In addition to the age variable, Wu et al. (2015) and Kiuru et al. (2016) found that students who had good communication with their teachers had less adaptation problems.

When the results of this study and similar studies in the literature are evaluated, it is seen that 60-65 months old students have more school adaptation problems than 66-71 and 72-84 months old students. Similarly, Ozarslan (2014) concluded that 60-71 months old students frequently exhibited adaptation problems such as wanting to play games, waiting for help from their teachers and getting tired quickly. In addition, 60-71 months old students had more difficulty in adapting to school than 72-84 months old students. In this case, it is seen that school adaptation problems decrease with age. Turan (2018) found that 67-72 months old students had better adaptation to school than 60-66 months old students. Similarly, Ensar and Keskin (2014) found that 60-66 months old children had lower levels of social-emotional adjustment to school than 66-72 months old children. Memisoglu and Ismetoglu (2013) stated that 60-72 months old students had more adaptation problems than the students of 72 months and above. Ercan (2016) concluded that five years old students had school adaptation 
problems more than older students. Similarly, Yoleri and Tanis (2014) found that seven years old children had better school adaptation than five years old children. Uzun (2015) and Guler (2016) concluded that school adaptation problems decreased with age. Zelyurt and Ozel (2015) reached similar results in their study. Isikoglu Erdogan and Simsek (2014) concluded that starting school at a young age had a negative effect on school adaptation process. Aykac, Kabaran, Arat and Bilgin (2014) found that 60 months old students had more adaptation problems than 72 months old students.

Based on the results of similar studies in the literature and this study's results, it can be said that students' school adaptation problems increased as the age of starting primary school decreased. In other words, it can be said that 60-65 months old students have more school adaptation problems than 66-71 months and 72-84 months old students. Although there are no significant age differences between the students, even four or five months cause many developmental differences. It can be said that 60-65 months old students have difficulty in adapting to the school because of the fact that they want to play constantly as they are in playing period, they do not have school perception, they are reluctant to participate in courses and lack motivation. In addition, 60-65 months old students are not ready for school in terms of cognitive, affective, psychomotor and self-care skills. School readiness is of paramount importance in fulfilling the duties and responsibilities of the school. Therefore, it is an expected result that 60-65 months old students, who are not ready for primary school, have difficulty in adapting to the school as they are unable to fulfill their duties and responsibilities. As a matter of fact, Polat et al. (2014) found that students, who are ready for school, adapt to school more quickly. It was determined that students older than 66 months were more ready for school than 60-65 months. School adaptation is also easier for the children who are ready for school. Therefore, it can be said that students' developmental characteristics, social-emotional development and readiness levels are effective on this result. Primary education has a significant impact on the child's future educational and even social life. When the spiral structure of education is taken into consideration, the failure that occurs in one of the educational steps will reflect to all educational levels. In this respect, it is very important for the students to adapt and be ready for school. In addition, being in an environment where they do not want or cannot adapt will cause irrelevant, low motivated individuals towards the courses. Therefore, school adaptation is very important for first grade students, especially 60-65 months old students.

In this study, it was concluded that students' school adaptation problems did not show significant difference according to gender. In parallel with the results of this study, Topcu (2012) found that school adaptation did not change according to gender. Similarly, Ensar and Keskin (2014) found that social emotional adjustment levels of children did not show significant difference according to gender. Ates (2016) found that gender was the lowest factor affecting school adaptation of primary school students. Although there are studies that overlap with the results of this study, there are also studies that differ from this study results. Wu et al. (2015) found that students' school adaptation levels differ significantly according to their gender. In the study conducted by Guler (2016) and Dirlik (2014), it was determined that girls' school adaptation levels were higher than boys. In contrast to this study, Isik (2007) found that girls had less adaptation to school than boys. In this case, it is seen that different results have been reached in studies concerning school adaptation problems of primary school students according to gender. Based on the results of this study, it can be said that male and female primary school students have similar school adaptation problems. 
In this study, it was determined that first grade primary school students in Van had more adaptation problems than the students in other provinces. Accordingly, it can be said that students who have education in provinces with limited socio-cultural opportunities have more problems with school adaptation. Numerous economic, social and cultural variables are included in the determination of socio-economic development level (Ministry of Development, 2013). Many of these variables directly or indirectly affect education processes (Kozikoglu, 2016). In this case; socio-economic status, cultural characteristics, individual differences (cognitive, affective and psychomotor characteristics) of students in low socio-economic development level and lack of supportive social environment can be considered as important reasons for students' having problems in school adaptation. As a matter of fact, Kozikoglu (2016) found that teachers working in provinces with low socio-economic development level had more difficulty in teaching-learning environment as the readiness levels of the students were low. Therefore, it can be said that low level of school readiness is also effective on the students who are studying in Van to have more adaptation problems than the students in other provinces.

In this study, it was determined that students having received preschool education experienced less adaptation problems than those who did not. This result supports similar study results in the literature. Zupancic and Kavcic (2011) determined that the students who received preschool education faced less adaptation problems in primary school. Similarly, in many studies conducted in the literature (Erdogan \& Simsek, 2014; Gedik, 2015; Guler, 2016; Isikoglu Erdogan \& Simsek, 2014; Topcu, 2012; Yesil, 2008; Yoleri \& Tanis, 2014), it was concluded that the students having received preschool education experienced less school adaptation problems than those who did not. In parallel with the results of this study, Ensar and Keskin (2014) found that students' social emotional level of school adaptation was higher in favor of the students who received preschool education; Akbasli and Uredi (2014) found that the students having received preschool education knew some rules and therefore they were more advantageous in terms of school adaptation than the children who did not. Based on the results of similar studies in the literature and the results of this study, it can be said that the children having received preschool education experience less school adaptation problems. In other words, it can be said that preschool education facilitates students' adaptation to school. It is known that preschool education has many benefits in terms of school adaption such as knowing the rules of school and class, obeying the rules, making friends, socializing, knowing the teacher and how to behave in the classroom (Ozarslan, 2014). The students having received preschool education are aware of what the school and the teacher are. This makes the school a less worrying place for students. However; the student, who has not received preschool education, does not know many things about the school. Students are afraid of school because they separate from their parents for the first time. Therefore, in the first weeks of school, students may experience many adaptation problems such as fear of separation from their families, crying, shyness and not communicating. In addition, it can be said that students having received preschool education have fewer problems in school adaptation and preparation process than the students who did not because they do activities in preschool education such as holding pencil, painting, line work and using scissors. However, the opposite situation exists for students who did not receive preschool education.

According to the results of this study, it was determined that school adaptation problems increase as the age of starting school decreases. Accordingly, it may be suggested to increase the age of starting school to at least 66 months. In addition, considering the individual differences between students, it can be suggested that the students starting primary school 
should not be evaluated only according to age criteria and they should be decided by applying maturity test for school. It was determined that all of the primary school students in different age groups experienced school adaptation problems such as willing to play constantly, lack of interest in school and courses, etc. It may be suggested for classroom teachers to conduct activities more fun and game-based. In this study, school adaptation problems of primary school students were determined. In future studies, academic success of the students who have started primary school at different ages can be examined comparatively or longitudinal studies can be conducted.

\section{References}

Akbasli, S., \& Uredi, L. (2015). An evaluation of the classroom teachers' attitudes towards the constructivist approach according to complexity theory: A case of Mersin. In S. S. Ercetin \& S. Banerjee (Eds.), Chaos, complexity and leadership 2013 (p. 419-434). UK: Springer Publishing.

Akis, G. (2018). Okul oncesi egitim kurumlarına devam eden 5-6 yas grubu cocukların okula uyumlarını yordayan degiskenlerin incelenmesi [Investigation of variables predicting the school adaptation of 5-6 years old children attending preschool education institutions] (Unpublished master thesis). Selcuk University: Social Sciences Institute.

Aslan, M. (2014). 60-72 aylik cocukların ilkokula baslama durumlarının incelenmesi [Examination of 60-72 months old children' starting to primary school] (Unpublished master thesis). Firat University: Educational Sciences Institute.

Ates, E. S. (2016). Sinıf ogretmenlerinin, ilkokul 1. sınıfa devam eden ogrencilerin okula uyumuna iliskin gorusleri [The opinions of classroom teachers about the adaptation of the students attending the first grade of primary school] (Unpublished master thesis). Gazi University: Educational Sciences Institute.

Aykac, N., Kabaran, H., Atar, E., \& Bilgin, H. (2014). Ilkokul 1. sinif ogrencilerinin 4+4+4 uygulamasi sonucunda yasadiklari sorunlarin ogretmen goruslerine dayali olarak degerlendirilmesi (Mugla ili ornegi) [Evaluation of the problems experienced by primary school 1st grade students as a result of $4+4+4$ applications based on the opinions of teachers (Mugla province case)]. International Periodical for the Languages, Literature and History of Turkish or Turkic, 9(2), 335-348.

Aypay, A., Aypay, A., \& Demirhan, G. (2009). Ogrencilerin universiteye sosyal uyumu: Bir universite ornegi [Social adaptation of students to university: An university case]. Usak Universitesi Sosyal Bilimler Dergisi, 2(1), 46-64.

Basar, M. (2013). 60-66 Ay aralıgında ilkokula baslayan ogrencilerin kisisel oz bakım ve ilkokuma-yazma becerilerinin ogretmen goruslerine gore degerlendirilmesi [Evaluation of the personal self-care and primary reading-writing skills of the students who started primary school between 60-66 months]. Turkish Studies International Periodical for the Languages, Literature and History of Turkish or Turkic, 8(8), 241- 252.

Basaran, I. E. (1994). Egitim psikolojisi [Education psychology]. Ankara: Kadıoglu Matbaası.

Basaran, S., Gokmen, B., \& Akdag, B. (2014). Okul oncesi ogrencilerinin okula uyum surecinde ogretmenlerin karsılastıgı sorunlar ve cozum onerileri [The problems faced by the teachers during the school adaptation process of preschool students and their solutions]. Uluslararası Turk Egitim Bilimleri Dergisi, 2(2), 197-223.

Birch, S. H., \& Ladd, G. W. (1997). The teacher-child relationship and children's early school adjustment. Journal of School Psychology, 35(1), 61-79. 
Buyukozturk, S., Cakmak, E. K., Akgun O. E., Karadeniz, S., \& Demirel, F. (2016). Bilimsel arastırma yontemleri (Scientific research methods). Ankara: Pegem Akademi Yayincilik.

Cerit, Y., Akgun, N., Yıldız, K., \& Soysal, M. R. (2014). Yeni egitim sisteminin $(4+4+4)$ uygulanmasında yasanan sorunlar ve cozum onerileri: Bolu il ornegi [Problems and solutions in the implementation of the new education system $(4+4+4)$ : Bolu province case]. Egitim Bilimleri Arastırmalar Dergisi, 4(1), 59-82.

Creswell, J. W. (2005). Educational research: Planning, conducting and evaluating quantitative and qualitative research. USA: Pearson Prentice Hall.

Creswell, J. W. (2014). Research design. qualitative, quantitative, and mixed methods approaches. USA: Sage Publications Inc.

Demirtas, S. Z. (2016). Ilkokul birinci sınıf ogrencilerinin okula uyumu: Bir model testi [First grade primary school students' adaptation to school: A model test] (Unpublished doctorate thesis). Hacettepe University: Educational Sciences Institute.

Dirlik, C. (2014). 4+4+4 egitim sisteminde 60-66 aylık ogrencilerin okula hazır bulunuslukta sosyal uyum duzeylerinin incelenmesi [Investigation of social adaptation levels of 60-66 month students in school readiness in 4+4+4 education system]. Istanbul Aydın University: Educational Sciences Institute.

Dogan, S., Kelleci, M., Sabanciogullari, S., \& Aydin, D. (2008). Bir ilkogretim okulunda ogrenim goren cocuklarda ruhsal uyum sorunları [Psychological adjustment problems in children studying in a primary school]. TSK Koruyucu Hekimlik Bulteni, 7(1), 47-52.

Durak, T. (2011). Okul oncesi cocuk ve ilk ogretmeni [Preschool child and his first teacher]. In M. O. Ulug \& G. Karadeniz (Eds.), Okul oncesi cocuk ve ... (p.23-44). Ankara: Nobel Yayıncilık.

Ensar, F., \& Keskin, U. (2014). Ilkokul birinci sinif ogrencilerinin okula uyumlari uzerine bir inceleme [A study on the adaptation of primary school students to school]. Egitimde Kuram ve Uygulama, 10(2), 459-477.

Entwisle, D. R., \& Alexander, K. L. (1998). Facilitating the transition to first grade: The nature of transition and research of factors affecting it. Elementary School Journal, 98(4), 381-397.

Ercan, H. (2016). Ilkogretim ogretmenlerinin ve yoneticilerinin 4+4+4 egitim sisteminin uygulama surecine iliskin gorusleri [Views of primary school teachers and administrators on the implementation process of the $4+4+4$ education system] (Unpublished master thesis). Gaziosmanpasa University: Educational Sciences Institute.

Fabian, H. (2000). Small steps to starting school. International Journal of Early Years Education, 8(2), 141-153.

Firat, M., Kabakci Yurdakul, I., \& Ersoy, A. (2014). Bir egitim teknolojisi arastirmasina dayali olarak karma yontem arastirmasi deneyimi [Experience in mixed method research based on an educational technology research]. Journal of Qualitative Research in Education, 2(1), 65-86.

Fidan, M., Tasci, G., \& Yilmaz, N. (2013, Mayıs). Ilkokul birinci sınıf ogretmenlerinin 60-66 aylık ogrencilere iliskin gorusleri [The views of primary school first grade teachers about students between 60-66 months]. XII. Uluslararası Katılımlı Ulusal Sınıf Ogretmenligi Sempozyumu, Aydın.

Gedik, S. (2015). Ogretmen algılarına gore 60-66 aylık cocuklarda okula uyumun incelenmesi: Fatih ilcesi ornegi [Examination of school compliance in 60-66 months old children according to teacher perceptions: Case of Fatih district (Unpublished master thesis). Yeditepe University: Educational Sciences Institute. 
Gill, S., Winters D., \& Friedman, D. S. (2006). Educators' views of pre-kindergarten and kindergarten readiness and transition practices. Contemporary Issues in Early Childhood, 7(3), $213-227$.

Goldberg, C. A. (2006). Transitioning to preschool: the role of withdrawn behavioral subtypes and the teacher-child relationship in early school adjustment (Unpublished master thesis). Northern Illinois University: Department of Psychology.

Guler, H. (2016). Ilkokul 1.sınıfa baslayan ogrencilerin okula baslama yasına gore okula uyumlarının ve okuma-yazma becerilerinin incelenmesi [Examination of the adaptation and literacy skills of the students who started the first year of primary school according to the age of starting school] (Unpublished master thesis). Giresun University: Educational Sciences Institute.

Gunduz, F., \& Calıskan, M. (2013). 60-66, 66-72, 72-84 aylik cocuklarin okul olgunluk ve okuma yazma becerilerini kazanma duzeylerinin incelenmesi [Investigation of school maturity level and literacy skills of 60-66, 66-72, 72-84 month old children]. International Periodical for the Languages, Literature and History of Turkish or Turkic, 8(8), 379-398.

Gunduz H. B., \& Ozarslan N. (2017). Farkli yas kategorilerinde ilkokula baslayan ogrencilerin okul olgunlugu ve ogretmen goruslerine gore okula uyum problemleri [School maturity and adaptation problems according to teachers' opinions of students who started primary school in different age categories]. Abant ilzzet Baysal Universitesi Egitim Fakultesi Dergisi, 17(1), 212-230.

Isik, M. (2007). Anasınıfina devam eden bes-alti yas cocuklarimplementation of social adaptation and skill scale for 5-6 aged preschool children] (Unpublished master thesis). Gazi University: Educational Sciences Institute.

Isikoglu Erdogan, N., \& Simsek, Z. C. (2014). Birinci sinifa baslayan cocuklarin, velilerin ve ogretmenlerin okula uyumlarinin incelenmesi [Examination of the adaptation of first grade children, parents and teachers to school]. International Journal of New Trends in Arts, Sports \& Science Education, 3(2), 62-70.

Johnson, B., \& Christensen, L. (2008). Educational research: Quantitative, qualitative, and mixed approaches. Needham Heights, MA: Allyn ve Bacon.

Johnson, R., \& Onwuegbuzie, A. (2004). Mixed methods research: A research paradigm whose time has come. Educational Researcher, 33(7), 14-26.

Kahramanoglu, R., Tiryaki, E. N., \& Canpolat, M. (2014). Ilkokula yeni baslayan 60- 66 ay grubu ogrencilerin okula hazir oluslari uzerine inceleme [An investigation on the readiness of $60-66$ months old students who have just started primary school]. Kastamonu Egitim Dergisi, 23(3), 1065-1080.

Kalkinma Bakanligi. (2013). Illerin ve bolgelerin sosyo-ekonomik gelismislik sıralaması arastırması: SEGE-2011 [Socio-economic development ranking survey of provinces and regions: SEGE2011]. Bolgesel Gelisme ve Yapisal Uyum Genel Mudurlugu.

Karatas, Z. (2015). Sosyal bilimlerde nitel arastırma yontemleri [Qualitative research methods in the social sciences]. Manevi Temelli Sosyal Hizmet Arastırmaları Dergisi, 1(1), 62-80.

Kiuru, N., Laursen, B., Aunola, K., Zhang, X., Lerkkanen, M. K., Leskinen, E., \& Nurmi, J. E. (2016). Positive teacher affect and maternal support facilitate adjustment after the transition to first grade. Merrill-Palmer Quarterly, 62(2), 158-178. 
Kozikoglu, I. (2016). Ogretimin ilk yılı: Meslegin ilk yılındaki ogretmenlerin karsılastıkları guclukler, hizmet oncesi egitim yeterlikleri ve meslege adanmılıkları [First year in teaching: Difficulties faced by teachers in the first year of the profession, pre-service training competencies and commitment to the profession] (Unpublished doctorate thesis). Van Yuzuncu Yıl University: Educational Sciences Institute.

Ladd, G. W., Birch, S. H., \& Buhs, E. S. (1999). Children's social and scholastic lives in kindergarten: related spheres of influence?. Child Development, 70, 1373-1400.

Ladd, G. W., \& Burgess, K. B. (2001). Do relational risks and protective factors moderate the linkages between childhood aggression and early psychological and school adjustment?. Child Development, 72, 1579-1601.

Ladd, G. W. (2003). Probing the adaptive significance of children's behavior and relationships in the school context: A child by environment perspective. In R. Kail (Ed.), Advances in child behavior and development (p. 43-104). New York: Wiley.

Memisoglu, S. P., \& Ismetoglu, M. (2013). Zorunlu egitimde $4+4+4$ uygulamasına iliskin okul yoneticilerinin gorusleri [Opinions of school principals about $4+4+4$ in compulsory education]. Egitim ve Ogretim Arastırmaları Dergisi, 2(2), 14-25.

Miles, M. B., \& Huberman, A. M. (1994). Qualitative data analysis. Thousand Oaks, CA: Sage Publications.

Milli Egitim Bakanligi Strateji Gelistirme Baskanligi. (2018). Milli egitim istatistikleri orgun egitim [National education statistics formal education]. Erisim adresi: https:// sgb.meb.gov.tr/meb_iys_dosyalar/2018_09/06123056_meb_istatistikleriorgun_egiti m_2017_2018.pdf].

Onder, A., \& Gulay, H. (2010). 5-6 yas cocukları icin okula uyum ogretmen degerlendirme olceginin guvenirlik ve gecerlik calısması [Reliability and validity study of the school adaptation teacher assessment scale for 5-6 aged children]. International Online Journal of Educational Scienes, 2(1), 204-224.

Ozarslan, N. (2014). Birinci sınıfta ogrenim gormekte olan (60-71 ve 72-84 aylık) ogrencilerin okul olgunlugu duzeyleri ve bu ogrencileri okutmakta olan ogretmenlerin gozledigi okula uyum ve sınıf yonetimi sorunları [School maturity levels of the first year students (60-71 and 72-84 months), school adaptation problems and classroom management observed by the teachers teaching these students] (Unpublished master thesis). Okan University: Educational Sciences Institute.

Ozgenel, S. (1992). Ilkokulun ilk gunlerinde cocuk [Child in the early days of primary school]. Yasadıkca Egitim, 24, 5-9.

Patton, M. Q. (2002). Qualitative research \& evaluation methods. USA: Sage Publications, Inc.

Polat, O., Kucukoglu, E. K., Niran S. S., Unsal, F. O., \& Yildiz, T. O. (2014). The comparison of 5466 months old children's readiness for primary school during preschool period and their adaptation to primary school. International Journal on New Trends in Education and Their Implications, 5(1), 169-182.

Punch, K. F. (2014). Sosyal arastırmalara giris: Nicel ve nitel yaklasımlar [Introduction to social research: Quantitative and qualitative approaches]. D. Bayrak, H. B. Arslan \& Z. Akyuz (Trans.). Ankara: Siyasal Kitapevi.

Sirem, O. (2014). 4+4+4 okul sisteminde sinıf ogretmenlerinin ilkokuma yazma ogretim surecine yonelik gorusleri: Duzce ili ornegi [Views of primary school teachers about the process of teaching reading and writing in primary school of 4+4+4 system: Duzce province case] (Unpublished master thesis). Duzce University: Educational Sciences Institute.

Topcu, Z. (2012). Okul oncesi egitimin ilkogretim birinci sınıf ogrencilerinin okula uyum ve Turkce dil becerilerine etkisi [The effect of preschool education on the adaptation and Turkish 
language skills of first grade primary school students] (Unpublished master thesis). Hacettepe University: Social Sciences Institute.

Topdemir, S. (2014). 4+4+4 uygulamasının okul yoneticilerinin goruslerine gore degerlendirilmesi: Diyarbakır il ornegi [Evaluation of 4+4+4 application according to the opinions of school administrators: Diyarbakır province case] Unpublished master thesis). Zirve University: Social Sciences Institute.

Turan, T. (2018). 4+4+4 egitim sisteminde 60-66 aylık cocukların okula erken baslamasının degerlendirilmesi [Evaluation of early starting of school children between 60-66 months in 4+4+4 education system] (Unpublished master thesis). Firat University: Educational Sciences Institute.

Ustabas, P. (2017). Ortaokul ogrencilerinin okula uyumunda okul yonetimi ve ogretmenlerden beklentileri: Hopa ilcesi ornegi [Expectations of secondary school students from school management and teachers in school adaptation: Hopa district case]. (Unpublished master thesis). Avrasya University: Educational Sciences Institute.

Uzun, E. M., \& Alat, K. (2014). Ilkokul birinci sınıf ogretmenlerinin 4+4+4 egitim sistemi ve bu sistem sonrasında ilkokula baslayan ogrencilerin hazırbulunuslukları hakkındaki gorusleri [The views of primary school first grade teachers about $4+4+4$ education system and the readiness of the students who started primary school after this system]. Abant Izzet Baysal Universitesi Egitim Fakultesi Dergisi, 14(2), 15-44.

Uzun, E. M. (2015). Okul oncesi donemde uygulanan "okula hazırız" egitim programının ilkokul birinci sınıf ogrencilerinin okula uyum ve hazırbulunusluk duzeylerine etkisi [The effect of "we are ready for school "education program in the preschool period on the adaptation and readiness levels of the first grade primary school students] (Unpublished doctorate thesis). Ondokuz Mayıs University: Educational Sciences Institute.

Wu,Y., Wu, J., Chen, Y., Han, L., Han, P., Wang, P., \& Gao, F. (2015). Shyness and school adjustment among Chinese preschool children: Examining the moderating effect of gender and teacher-child relationship. Early Education and Development, 26, 149-166.

Yavuzer, H. (2014). Okul cagı cocugu [School age child]. Istanbul: Remzi Kitabevi.

Yesil, D. (2008). Okul oncesi egitim almıs ve almamıs ogrencilerin okula uyumlarının karsilastırılması [Comparison of the adaptation of preschool and non-preschool students] (Unpublished master thesis). Yeditepe University: Educational Sciences Institute.

Yildirim, A., \& Simsek, H. (2011). Sosyal bilimlerde nitel arastırma yontemleri [Qualitative research methods in the social sciences]. Ankara: Seckin Yayıncılık.

Yoleri, S., \& Tanis, H. M. (2014). Ilkokul birinci sinif ogrencilerinin okula uyum duzeylerini etkileyen degiskenlerin incelenmesi [Investigation of the variables affecting the adaptation levels of primary school students]. Sosyal Bilimler Enstitusu Dergisi, 4(2), 130-141.

Yorukoglu, A. (2003). Cocuk ruh saglıgı, cocugun kisilik gelisimi egitimi ve ruhsal sorunları [Child's mental health, child's personality development education and mental problems]. Istanbul: Ozgur Yayınları.

Yorukoglu, A. (2006). Cocuk ruh saglıgı [Child's mental health]. Istanbul: Ozgur Yayınları.

Zelyurt, H., \& Ozel, E. (2015). Ilkokul birinci sınıfı okutan sınıf ogretmenlerinin egitimde 4+4+4 duzenlemesine iliskin gorusleri [The views of primary school first grade classroom teachers about 4+4+4 arrangement in education]. Ahi Evran Universitesi Kırsehir Egitim Fakultesi Dergisi, 16(3), 1-18. 
Zupancic, M., \& Kavcic, T. (2011). Factors of social adjustment to school: child's personality, family and pre-school. Early Child Development and Care, 181(4), 493-504.

\section{Biographical notes:}

Kayahan ÇÖKÜK is currently working as an classroom teacher in Van/Turkey and completed his master degree at Van Yüzüncü Yıl University, Department of Educational Sciences, Division of Curriculum and Instruction.

Dr. İshak KOziKoĞLU is an Assistant Professor in the Department of Educational Sciences, Division of Curriculum and Instruction, at Van Yüzüncü Yıl University, Turkey. His current research interests are curriculum studies, instructional issues, teacher education, language education, cultural issues and teacher professional development. 